\title{
Model MPPT Metode Fractional Short Circuit Current Menggunakan JST - AG untuk Solar Panel
}

\section{Short Circuit Current Fractional Method MPPT Model by JST - AG for Solar Panel}

\author{
Gunawan Wibisono1,*, Herryawan Pujiharsono2 \\ ${ }^{1,2}$ Program Studi Teknik Elektro, \\ Fakultas Teknik Telekomunikasi dan Elektro, Institut Teknologi Telkom Purwokerto \\ Jl. D.I. Panjaitan 128, Purwokerto, Jawa Tengah, Indonesia \\ 1,*Penulis korespondensi: wibisono@ittelkom-pwt.ac.id \\ ${ }^{2}$ herryawan@ittelkom-pwt.ac.id
}

Received on 14-12-2018, accepted on 26-01-2019, published on 28-01-2019

\begin{abstract}
Abstrak
Sistem photovoltaic memerlukan sebuah metode untuk meningkatkan efisiensi konversinya. Salah satu metodenya adalah menggunakan maximum power point tracking (MPPT). Salah satu metode MPPT, adalah metode fractional short circuit current. Metode ini sediri dapat dioptimalkan lebih jauh menggunakan jaringan syaraf tiruan. Jaringan syaraf tiruan sendiri dapat dilatih menggunakan algoritma genetika. Dengan menggunakan algoritma genetika untuk melatih jaringan syaraf tiruan, didapatkan nilai mean square error (MSE) pelatihan berkisar antara 0,000690983-0,003210547, dengan rata-rata sebesar 0,002499517 . Sedangkan error pengujian berada pada rentang $8,91 \%-13,21 \%$.
\end{abstract}

Keywords: Algoritma Genetika, Jaringan Syaraf Tiruan, MPPT, , Photovoltaic

Abstract

The photovoltaic system requires a method to increase its conversion efficiency. One method is to use maximum power point tracking (MPPT). One of the MPPT methods is the fractional short circuit current method. This method itself can be further optimized using an artificial neural network. The artificial neural network itself can be trained using genetic algorithms. By using a genetic algorithm to train artificial neural networks, the mean square error (MSE) value of the training ranged from $\mathbf{0 . 0 0 0 6 9 0 9 8 3 -}$ 0.003210547 , with an average of 0.002499517 . While the test error is in the range of $8.91 \%-13.21 \%$.

Keywords: Genetic Algorithm, Artificial Neural Network, MPPT, Photovoltaic

\section{Pendahuluan}

Salah satu alternatif energi terbarukan yang mulai berkembang aplikasinya adalah sistem photovoltaic $(\mathrm{PV})$. Sistem ini menggunakan semikonduktor untuk menghasilkan energi listrik langsung dari energi matahari. Potensi energi surya yang diterima bumi (di luar atmosfer) adalah 1300 watt $/ \mathrm{m} 2$. Namun demikian, efisiensi konversinya tergolong rendah. Pada sel PV komersial maksimal hanya sekitar 20\% [1]. Ada beberapa metode untuk meningkatkan efisiensi konversi sel PV, antara lain menggunakan metode Maximum Power Point Tracking (MPPT).

MPPT menjejak (track) titik kerja/titik daya sebuah sumber energi agar menghasilkan daya maksimum, dengan menggunakan metode/ algoritma tertentu [2]. Daya output maksimum sel PV terjadi pada nilai arus 
dan tegangan tertentu, tergantung beban dan kondisi atmosfer pada saat itu. Kendali MPPT memungkinkan terjadinya efisiensi konversi energi yang tinggi meskipun kondisi beban dan kondisi atmosfer selalu berubah.

Kendali MPPT dapat diwujudkan dengan berbagai metode, seperti metode konduktasi inceremental, metode perturb and observe, serta metode tegangan konstan. Masing masing metode ini memiliki kelebihan dan kekurangan [3].

Menurut Utami, MPPT metode perturb and observe dapat menaikkan output daya dari 15,37 watt (metode konvensional) menjadi 24,49 watt. [4]

Salah satu metode MPPT adalah metode fractional short circuit current. Sebagaimana metode fractional open voltage, metode ini mudah diterapkan, sederhana, namun kurang fleksibel. Ketidakfleksibelan ini terkait dengan penyesuaikan kondisi beban dan kondisi lingkungan. Untuk mengatasi ketidakfleksibelan ini, dapat digunakan sebuah jaringan syaraf tiruan untuk menentukan parameter fractional-nya. Sedangkan JSTnya sendiri dapat dilatih dengan menggunakan algoritma genetika.

\section{Metode Penelitian}

Dalam penelitian ini, dibutuhkan data awal, yaitu data arus dan tegangan output solar panel, pada suhu, pencahayaan, dan beban yang bervariasi. Data primer ini kemudian diolah untuk mendapatkan data latih, berupa suhu (T), data daya maksimum (Pmax), dan arus maximum-power (Iref).

\section{A. Data Awal}

Data awal diperoleh langsung secara eksperimen menggunakan solar panel, dan beban resistor variabel. Alat ukur yang digunakan adalah solar power meter untuk mengukur daya matahari, termometer untuk mengukur suhu panel, serta voltmeter dan amperemeter untuk mengukur keluaran panel. Rangkaian pengukuran dapat dilihat pada Gambar 1 berikut.

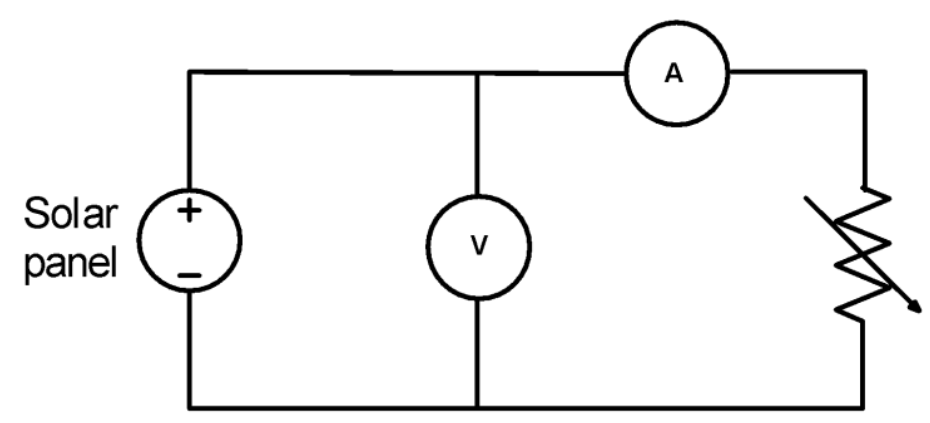

Gambar 1. Rangkaian pengambilan data awal

Hasil pengukuran diolah untuk mendapatkan kurva daya output (P) sebagai fungsi arus output (I). Kurva daya untuk suhu $41^{\circ} \mathrm{C}$ dan tingkat pencahayaan $770 \mathrm{~W} / \mathrm{m} 2$ dapar dilihat pada Gambar 2 berikut.

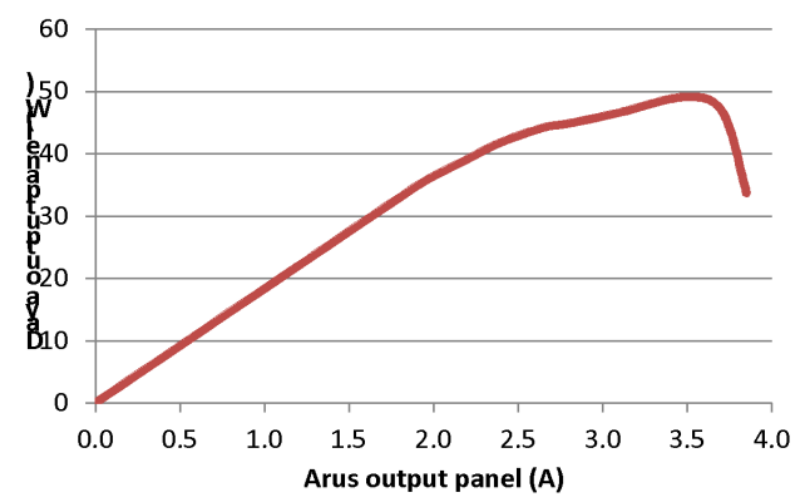

Gambar 2. Kurva daya output solar panel 
Dari kurva tersebut diambil data arus hubung singkat (Isc) dan arus keluaran panel saat daya maksimum (Iref). Dua data tersebut digabungkan dengan data suhu panel yang bersesuaian dengan kurva yang bersangkutan. Untuk keperluan pelatihan jaringan syaraf tiruan, diambil 20 set data, pada berbagai kondisi pencahayaan dan berbagai suhu panel.

\section{B. Konversi Nilai}

Data arus dan suhu kemudian dikonversi ke dalam format 10-bit, sehingga nantinya mudah jika akan diterapkan pada mikrokontroler dengan ADC 10-bit.

Data arus ( $\mathrm{I}_{\mathrm{sc}}$ dan $\left.\mathrm{I}_{\text {ref }}\right)$ dikonversi dengan nilai arus maksimum 10 A menggunakan rumus berikut:

$$
I_{(10-b i t)}=\frac{1023}{10} \times I_{(\text {ampere })}
$$

Sedangkan data suhu dikonversi dengan nilai suhu maksimum $100^{\circ} \mathrm{C}$ dengan rumus berikut:

$$
T_{(10-b i t)}=\frac{1023}{100} \times T_{\left({ }^{\circ} \mathrm{C}\right)}
$$

\section{Jaringan Syaraf Tiruan}

Dua puluh set data tersebut kemudian digunakan untuk pelatihan dan pengujian Jaringan Syaraf Tiruan (JST). Tiga set data dipilih secara acak digunakan sebagai data uji, sedangkan sisanya sebanyak 17 set data digunakan sebagai data latih. Tiga set data yang dipilih secara acak ini berbeda-beda di setiap pelatihan.

Adapun jaringan syaraf tiruan yang digunakan ditunjukkan pada Gambar 3 berikut.

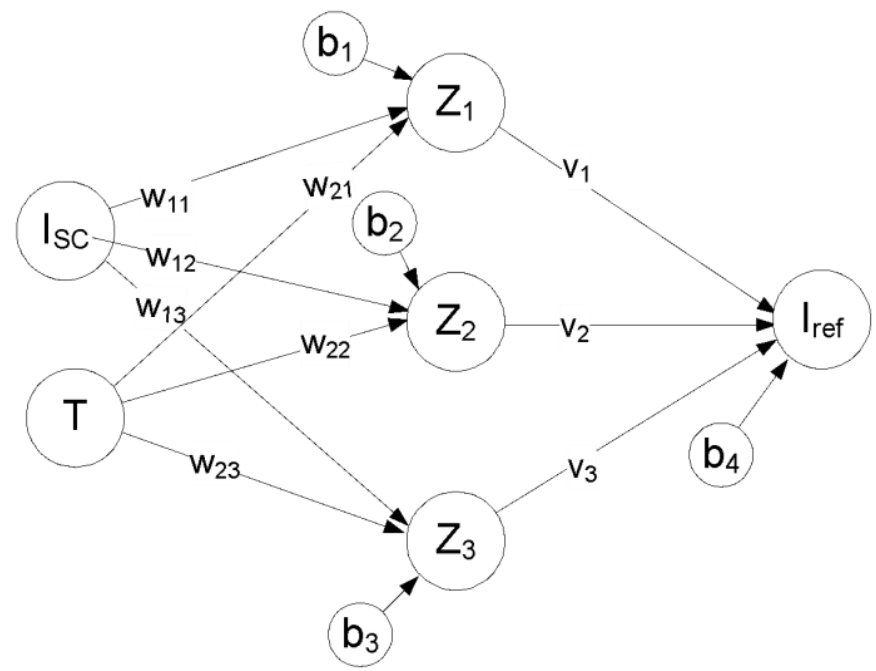

Gambar 3. Jaringan syaraf tiruan yang digunakan

JST yang digunakan memiliki 3 lapis. Lapis input dengan 2 node $\left(\mathrm{I}_{\mathrm{sc}}\right.$ dan $\left.\mathrm{T}\right)$, lapis output dengan 1 node ( $\mathrm{I}_{\text {ref }}$ ). Kemudian, lapisan tersembunyi $\mathrm{Z}$ sebanyak 3 node digunakan untuk mengantisipasi ketidaklinieran sistem.

Fungsi aktifasi yang digunakan dalam jaringan adalah fungsi sigmoid. Untuk lapisan tersembunyi Z, fungsi sigmoid yang digunakan menggunakan faktor pengali 1 (satu), sedangkan pada lapisan output, menggunakan faktor pengali 1023 (10-bit). Dengan menggunakan faktor pengali 1023, maka lapisan output bisa langsung digunakan untuk aplikasi mikrokontroler. 


\section{Algoritma Genetika}

Jaringan syaraf tiruan tersebut kemudian dilatih menggunakan algoritma genetika (AG). Weight dan bias dari JST dimodelkan sebagai kromosom pada algoritma genetika. Sehingga setiap 'individu' pada algoritma genetika, memiliki 13 kromosom ( $\mathrm{w}_{11}-\mathrm{w}_{23}, \mathrm{v}_{1}-\mathrm{v}_{3}$, dan $\left.\mathrm{b}_{1}-\mathrm{b}_{4}\right)$.

Dalam pelatihan digunakan parameter-parameter sebagai berikut:

jumlah populasi: 2000

jumlah generasi: 100

tingkat mutasi: $0,5 \%$

tingkat pindah silang heuristik: $80 \%$

tipe seleksi: normalized geometry

Untuk mendapatkan hasil terbaik, pelatihan AG dilakukan sebanyak 8 kali, masing-masing sebanyak 100 pelatihan, sehingga total jumlah pelatihan adalah 800 kali. Hal ini dilakukan untuk mengantisipasi sifat acak dari pelatihan AG.

Proses pelatihan AG dilakukan menggunakan genetic algorithm optimization toolbox (gaot), yang diterapkan pada software open source GNU Octave.

Output dari pelatihan berupa nilai mean square error (MSE). Semakin kecil nilai MSE maka hasil pelatihan semakin baik. Untuk nilai MSE terkecil, akan dilakukan pengujian menggunakan data uji, untuk mendapatkan nilai error rata-rata.

\section{Hasil dan Pembahasan}

Dari 800 kali pelatihan didapatkan nilai MSE minimal sebesar 0,000690983. Nilai MSE terbesar sebesar 0,003210547. Sedangkan rata-rata MSE didapatkan nilai sebesar 0,002499517. Sebaran nilai MSE dari 800 pelatihan dapat dilihat pada Gambar 4.

Dari Gambar 4 terlihat bahwa sebagian besar nilai MSE berada pada rentang 0,00209-0,00309.

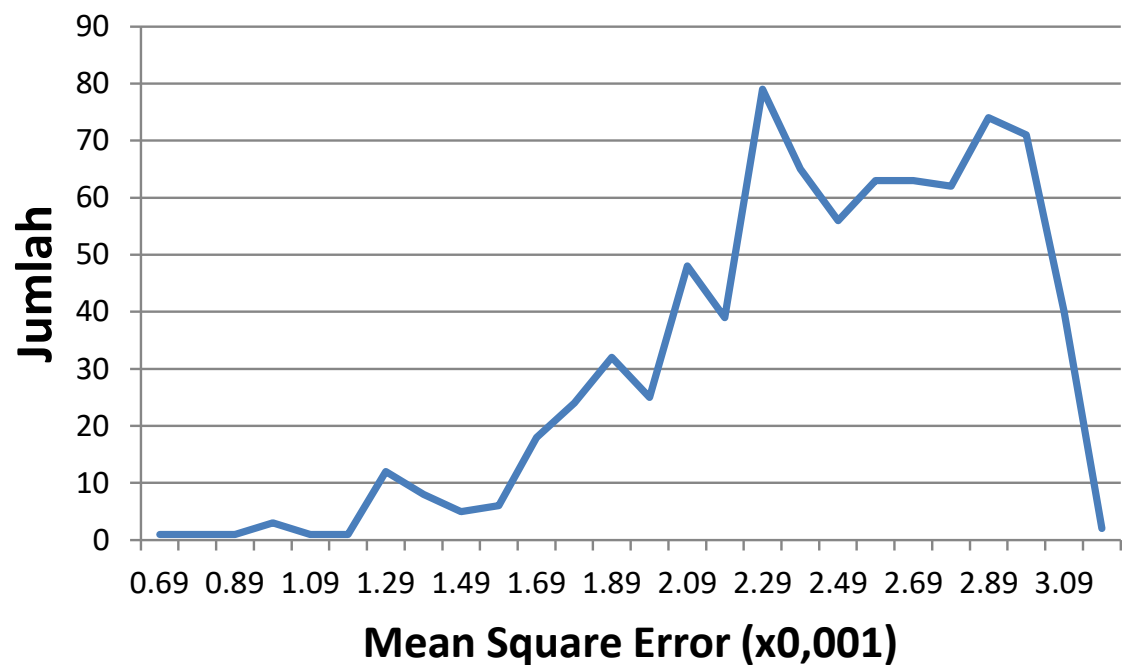

Gambar 4. Sebaran Mean Square Error

Contoh detail proses tiap pelatihan menggunakan algoritma genetika dapat dilihat di Gambar 5. Dari grafik tersebut terihat bahwa MSE terbaik semakin berkurang (semakin baik), jika generasi semakin tua. Terlihat fluktuasi pada MSE rata-rata populasi. Fluktuasi ini disebabkan oleh faktor mutasi. Demikian juga MSE terbaik yang menurun secara tiba-tiba di generasi ke-60, juga disebabkan oleh faktor mutasi. 


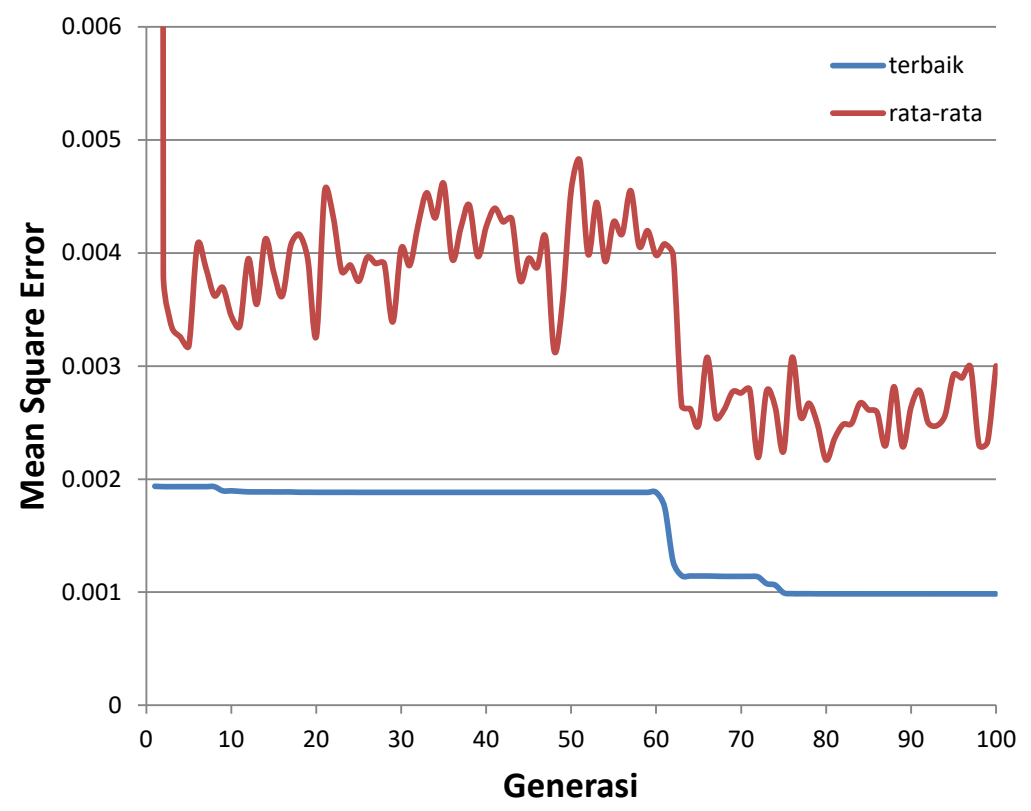

Gambar 5. Contoh proses pelatihan

MSE terbaik dari tiap 100 kali pelatihan ditunjukkan pada Gambar 6. Dari gambar tersebut terlihat bahwa pada generasi di atas generasi ke-80, tidak terjadi perbaikan MSE yang signifikan.

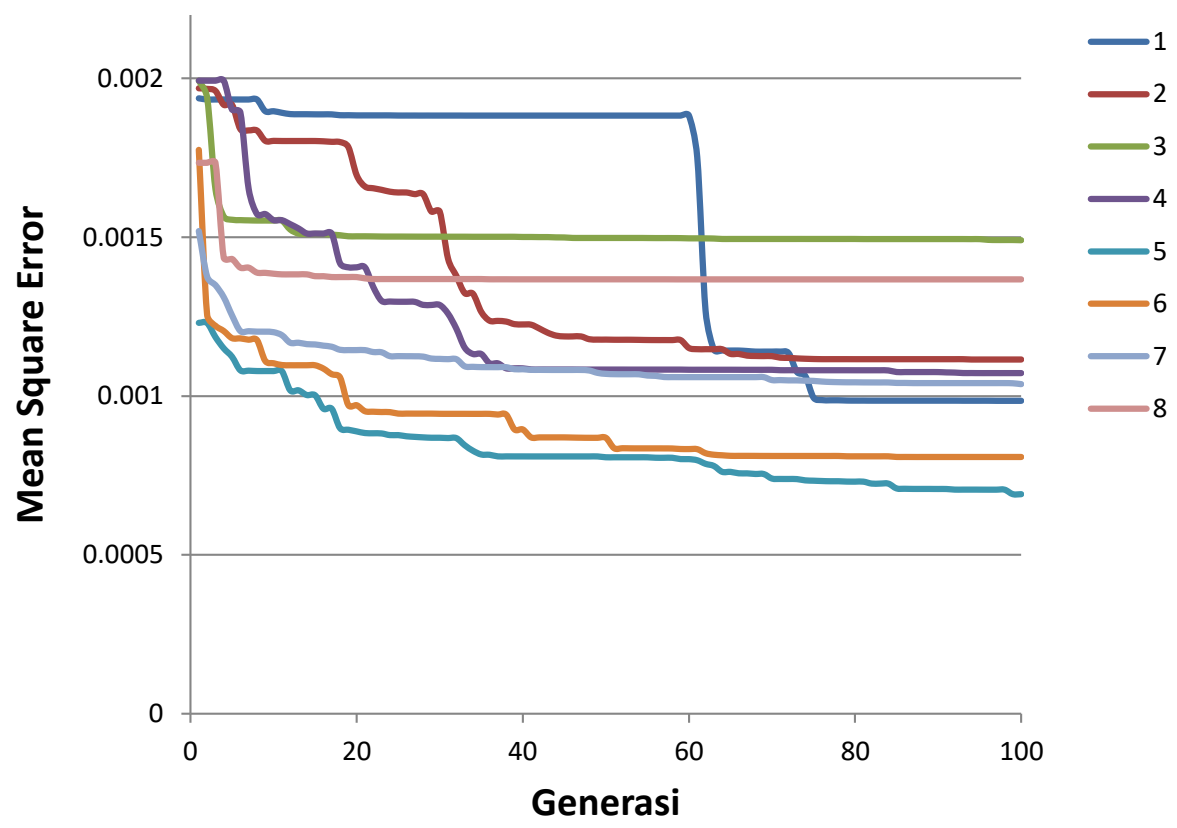

Gambar 6. Delapan MSE terbaik

Dari 800 kali pelatihan tersebut didapatkan 8 parameter model JST terbaik yang bisa diterapkan. Parameter tersebut ditampilkan pada Tabel 1 berikut. 
TABEL I

Parameter Model JST Terbaik

\begin{tabular}{|c|c|c|c|c|c|c|c|c|c|c|c|c|c|}
\hline $\mathbf{N o}$ & $\mathbf{w}_{\mathbf{1 1}}$ & $\mathbf{w}_{\mathbf{1 2}}$ & $\mathbf{w}_{\mathbf{1 3}}$ & $\mathbf{w}_{\mathbf{2 1}}$ & $\mathbf{w}_{\mathbf{2 2}}$ & $\mathbf{w}_{\mathbf{2 3}}$ & $\mathbf{v}_{\mathbf{1}}$ & $\mathbf{v}_{\mathbf{2}}$ & $\mathbf{v}_{\mathbf{3}}$ & $\mathbf{b}_{\mathbf{1}}$ & $\mathbf{b}_{\mathbf{2}}$ & $\mathbf{b}_{\mathbf{3}}$ & $\mathbf{b}_{\mathbf{4}}$ \\
\hline 1 & 0.687 & 0.629 & -1.000 & -0.375 & -0.340 & 0.441 & 0.714 & -0.660 & 0.998 & -0.993 & -0.849 & 1.000 & 0.671 \\
\hline 2 & 0.933 & 0.491 & 0.387 & -0.521 & -0.265 & -0.231 & 0.995 & -0.348 & -0.996 & 1.000 & -0.481 & 0.996 & 0.683 \\
\hline 3 & 0.395 & 0.153 & 0.946 & -0.112 & -0.087 & -0.538 & 0.099 & -0.401 & -1.000 & 0.067 & 0.825 & 0.996 & 0.606 \\
\hline 4 & 0.752 & -0.940 & -0.236 & -0.406 & 0.520 & 0.137 & -0.316 & -0.371 & 0.120 & -0.515 & -1.000 & -0.983 & 0.923 \\
\hline 5 & -0.463 & 0.863 & -0.973 & 0.248 & -0.482 & 0.535 & 0.169 & 0.590 & -0.059 & 0.983 & 0.369 & 0.825 & 0.599 \\
\hline 6 & 0.969 & -0.956 & -0.576 & -0.523 & 0.542 & 0.321 & -0.309 & 0.675 & -0.307 & -0.748 & -0.993 & -0.997 & 0.335 \\
\hline 7 & 0.897 & 0.604 & -0.820 & -0.397 & -0.328 & 0.453 & -0.202 & -0.236 & -0.081 & 0.135 & 0.995 & -0.380 & 0.994 \\
\hline 8 & -0.279 & -0.071 & 0.994 & 0.158 & 0.025 & -0.586 & 0.435 & 1.000 & -0.997 & -1.000 & 0.999 & 0.986 & 0.237 \\
\hline
\end{tabular}

Sedangkan nilai error pengujian rata-rata untuk tiap MSE pelatihan terbaik ditunjukkan pada Tabel 2 berikut.

TABEL I

Error Pengujian untuk tiap MSE

\begin{tabular}{|c|c|c|}
\hline No & MSE pelatihan (x1000) & Error pengujian \\
\hline 1 & 0,984946 & $9,53 \%$ \\
\hline 2 & 1,114965 & $10,91 \%$ \\
\hline 3 & 1,490482 & $8,91 \%$ \\
\hline 4 & 1,072101 & $9,46 \%$ \\
\hline 5 & 0,690983 & $13,21 \%$ \\
\hline 6 & 0,808075 & $11,25 \%$ \\
\hline 7 & 1,037404 & $10,82 \%$ \\
\hline 8 & 1,367224 & $10,48 \%$ \\
\hline
\end{tabular}

Dari Tabel 1 tersebut terlihat bahwa untuk nilai MSE terbaik (0,000690983) justru mempunyai error pengujian terburuk $(13,21 \%)$. Sedangkan MSE terbaik kedua juga mempunyai error terburuk kedua juga. Sebaliknya error terbaik terjadi pada MSE terburuk.

Nilai MSE pelatihan dan error pengujian ini masih lebih buruk daripada metode optimasi berbasis Fractional Open Voltage.

Pada metode fractional open voltage didapatkan nilai Nilai MSE terbaik yang didapatkan adalah sebesar 0,000453. Sedangkan error rata-ratanya adalah 0, 9495\% [5]

\section{KeSIMPULAN}

Dari hasil dan pembahasan di atas, dapat diambil kesimpulan sebagai berikut:

1. MSE pelatihan berkisar antara 0,000690983-0,003210547, dengan rata-rata sebesar 0,002499517.

2. Sebagian besar MSE berkisar di rentang nilai 0,00209-0,00309.

3. Error pengujian berada pada rentang $8,91 \%-13,21 \%$

4. Hasil yang didapatkan dengan metode fractional short circuit current lebih buruk daripada metode fractional open voltage.

\section{UCAPAN TERIMA KASIH}

Penelitian ini didanai oleh Kementrian Ristekdikti dengan skema Penelitian Dosen Pemula nomor DIPA042.06.1.401516/2018. 


\section{DAFTAR PUSTAKA}

[1] Markvart, T dan Castaner, L., Practical Handbook of Photovoltaic, Fundamental and Aplication. Elsevier Oxford, ISBN 1-85617390-9, 2003.

[2] Kerekes, T dkk., MPPT algorithm for Voltage Controlled PV Inverters Maximum Power Point Tracking Controller for PV Systems using a PI Regulator with Boost DC/DC Converter , 2003.

[3] Esram, T dan Chapman, P.L., "Comparison of Photovoltaic Array Maximum Power Point Tracking Techniques". IEEE Transactions On Energy Conversion, Vol. 22 No. 2, Juni, 2007.

[4] Utami, Sri., "Implementasi Algoritma Perturb and Observe untuk Mengoptimasi Daya Keluaran Solar Cell Menggunakan MPPT." Jurnal Infotel vol.9 no 1., pp 92-99, Feb. 2017

[5] Wibisono, Gunawan dkk., "MPPT Menggunakan Metode Hibrid JST dan Algoritma Genetika Untuk Sistem Photovoltaic". Jurnal EECCIS Vol. 8, No. 2, pp 181-186, Des 2014 